\title{
Language, communication, and the politics of hope: Solidarity and work in the Italian migration infrastructure
}

Alfonso Del Percio

\author{
University College London \\ a.percio@ucl.ac.uk \\ Edited by Cadenza Academic Translations
}

\section{Introduction $^{1}$}

This article examines the forms of hope and solidarity pursued by social cooperatives in Italy. I focus on two cases that I ethnographically documented between summer 2014 and spring 2016, which have allowed me to investigate the role that language plays in the everyday work that cooperatives do with and for transnational workers, as well as its role in the attempts of these cooperatives to support these individuals' access to employment and socioeconomic independence. In the aforementioned context, language encompasses communicative practices such as enregistered modes of talk, speculations around behavioral scripts and normative modes of speaking, as well as modern ideologies about language as a bounded cultural entity. I also document the power relations that frame how social cooperatives operate on the ground, how they invest in and strategize around language, as well as how they make sense of their activities.

This account is informed by scholarship on migration that studies the intersection between the transnational circulation of individuals and social inequality through an investigation of the infrastructure that mediates, organizes, and shapes mobility (Xiang and Lindquist 2015). In Italy, where I studied the management of transnational migration (Del Percio 2016), this infrastructure consists of a complex network of institutional agents. It

\footnotetext{
${ }^{1}$ Thanks to the editors and the reviewers for their thought-provoking comments.
} 
encompasses governmental actors such as the police, the border control service, the navy, immigration services, public and private schools, local municipalities, as well as charities, NGOs, social enterprises, and migration agencies.

Social cooperatives are key actors within this infrastructure. Historically, they were linked to the left-wing student and workers' movement in Italy during the 1960s and 1970s. Their aim was to promote principles of community, solidarity, and redistribution, and to challenge capitalist maxims that put accumulation and the concentration of wealth at the center of economic transactions (Cannavò 2018). Along with larger criticisms of capitalism, the propagation of social cooperatives in Italy since the 1970s is also linked to an attempt to reorganize processes of economic production and exchange around the needs of economically weaker layers of the population (Satgar 2007). Given the radical projects of hope that were pursued and their alignment with transnational networks of left-wing activism and struggle, social cooperatives have, for many decades, been considered a threat to national security by the national government and have been subjected to forms of stigmatization and criminalization (Neri Serneri 2012).

Recently, however, social cooperatives have turned into important players for the state management of migration in Italy. While many social cooperatives were initially funded by actors contesting the subordination of people to state violence and control, today social cooperatives collaborate with state authorities when it comes to the provision of welfare and education. These transformations have occurred within the framework of a changing legislation in Italy implemented in the 1990s that subjects social cooperatives to increased surveillance as well as to forms of corporatization and commodification of their activities (Thomas 2004). Social cooperatives' collaboration with state authorities and the re-centering of their projects around the needs of displaced individuals are also linked to a changing mode of state governance that regulates the transnational mobility of people through actors from 
civil society who are paid to provide displaced individuals with language instruction, translation and interpreting services, legal and financial advice, housing and health care services, job counseling, and vocational education.

The two social cooperatives that are at the center of my ethnography are a part of these transformations. They operate in Rome, Italy and have recently refocused their projects toward the needs of transnational workers. The first, Co-op Donne e Lavoro [Co-op Women and Work], has historically been active in the domain of women's integration into the labor market. Today, it mainly focuses on projects promoting displaced women's access to work. The second, Libertà e Giustizia Sociale [Freedom and Social Justice], was founded in the 1970s to provide moral support to incarcerated, leftist political prisoners and has since turned to projects addressing the professional integration of ex-prisoners, especially people with a so-called "migration background."

In what follows, I document two projects pursued by these two cooperatives. I introduce the social workers that are involved in these projects and produce a detailed description of the communicative strategies invested in by these workers to mitigate the precarious social and economic positions of the transnational individuals they are working with. I also discuss the strategies developed by social workers to navigate the racializing discourses that transnational workers are confronted with in Italy and that complicate their access to symbolic and material resources. I then reflect on what these two cases allow me to say, conceptually and theoretically, about why language is invested in by these workers in the way it is, about what these communicative resources enable social workers to do, as well as about the effects of this strategizing around language on social workers' ability to cope with the subalternization of transnational workers in Italy.

By doing so, I argue that, just like the state, whose management of inequality is framed by ideologies of colonialism and gendered/racialized nationalism, social cooperatives 
in Italy manage the contradiction between liberal democratic promises of access and social selection through mystification processes that rely on language and communication, as well as on powerful imaginations of culture and the self. Indeed, while in both cases presented, specific modes of speaking are invested in to manage the value of transnational workers' labor power and the value of commodities these workers produce, instead of challenging inequality, this strategizing around language contributes to the reproduction of long known about hierarchies and forms of difference. I will further argue that this persisting investment in language as a resource for social inclusion can be explained by the fact that structurally, social cooperatives operate according to logics imposed by the state, which frame how cooperatives act in favor of equality and change. This can also be explained by the powerful liberal ideas about language, work, and citizenship, and about the moral worth attached to certain kinds of gendered and racialized people as potential workers (and therefore citizens) that saturate cooperatives' activities and that complicate their possibility of pursuing alternative futures for transnational workers.

\section{1. "Empowering" workers}

The first case discussed draws on the work carried out by Donne e Lavoro, a social cooperative that aims to help integrate women into formal employment. I gained access to this cooperative through Carlo, one of its social workers. I had met Carlo at a workshop in Rome on the employability of low-skilled workers. Carlo's work at Donne e Lavoro consists of supporting women in their attempts to identify job opportunities. Sometimes, he is also able to broker jobs in local industries. When I met him in his office, Carlo explained that in recent years he had been able to develop contacts with employers, especially in the local tourism industry, which is one of the major economic sectors in Rome. In the high season, Carlo noted, when the local hotels need additional workforce, some of its managers ask him to provide them with workers willing to labor on a so-called "voucher basis." 
Voucher contracts are part of the deregulated regime of work under which both "transnational" and "local" workers labor in Italy. The voucher system enables employers to recruit laborers for a fixed number of hours without needing to provide them with stable contracts or social benefits. For the employers, this measure allows them to recruit cheap labor and enables them to let workers go once they are no longer needed. For the workers, voucher contracts are an easy way of accessing employment, allowing them to gain experience that is then said to facilitate the stabilization of their work situation. Carlo, however, fears that these labor schemes come with a risk, namely that workers move from one voucher contract to another and remain in precarious work positions.

He therefore organizes short training sessions in which those individuals who have accepted one of the voucher contracts he has negotiated for them "are prepared," he says, to make a good impression. For example, he meets them after his counseling sessions with other unemployed workers, provides them with some information about professional practice, explains their labor rights, and provides them with a bit of language instruction. This, Carlo notes, helps them to increase their probability of becoming stabilized and keeping their jobs. He is not able to provide them with formal training as he is not an educator, nor is the cooperative able to pay for professional (re)qualification. Many of the workers that Donne e Lavoro serve have worked as nannies or care workers (sometimes also as cleaners or waiters), but lack the qualifications to access qualified, formal, and wellremunerated jobs.

In summer 2015, Carlo asked me to join one of these informal training sessions. He had been able to broker short-term contracts for the three individuals who were on a program for so-called "victims of human trafficking" and had been "assigned" to Donne e Lavoro by the local social services - this is how Carlo explained to me the relationship of his cooperative to the three individuals. Two of them were Mira and Maria, two women from Bulgaria who had been caught stealing wallets. The third was Mais, a woman from Somalia who had worked in Rome's sex industry and who, being a minor, had been handed over to social services. 
When I first attended the training sessions, Carlo was presenting them with a textbook that was provided to him by one of his colleagues who is a careers advisor for tourism workers. This textbook had been developed by the "Federation of Italian Hotels and Tourism Associations" and was geared toward future chambermaids. It was structured in three parts: a first discussing what it means to be professional in the hotel industry, a second instructing students how to clean rooms, and a third explaining job security. In the previous sessions, he had informed them about the different types of labor contracts. He had also distributed some lists with concepts pertaining to tourism work. That day, Carlo explained what it meant to be professional. The textbook was clear about how maids in hotels were expected to behave at work.

The first aspect, Carlo noted, regards workers' attitudes toward customers, co-workers, and line managers. Hotels are busy workplaces, he explained, and workers are exposed to heavy workloads. In this situation, it is important to be respectful even if one gets harassed. Often, one would like to instinctively respond to criticism, he added, but our professionalism requires us to accommodate the needs of our interlocutors. The second aspect, Carlo continued, is the way that one presents oneself. Obviously, he remarked, it is essential to be punctual and follow instructions. But what is also important is to keep monitoring your uniform, adjusting your body language, checking your nails, examining your hairstyle, and to be polite and maintain good personal hygiene. Often, he explained, workers neglect these aspects because they are busy. Physical appearance, however, is important, especially in upper echelon hotels such as the one in which the three of them would work. Finally, Carlo added, a third aspect of being professional, which he called the "smile culture." This involves being good at communicating with customers and also smiling even if you really do not feel like doing so. He encouraged us to read some interactions presented on page 11 of the textbook ( $p$ for personnel; c for customer):

p - "Posso rifare la camera?" sorridere c - "No... vorrei prima lavarmi..." 
p - “Come desidera. Ripasserò dopo" sorridere

oppure

p - "Posso rifare la camera?" sorridere

c - “Non ha visto il cartellino di 'non disturbare'?”

p - "Mi deve infinitamente scusare. Il carrello mi aveva coperto la visuale. Vado subito via"

oppure

p - "Buon giorno signore. Le auguro una buona giornata!" sorridere ${ }^{2}$

(Federalberghi, 2009)

${ }^{2} \mathrm{p}-$ - Can I make your room?" smile

c - "No... I would like to take a shower first"

p - "As you wish, I will come back later smile

or

$\mathrm{p}$ - “Can I make your room?" smile

c- "Haven't you seen the 'do not disturb' sign?"

$\mathrm{p}$ - "I deeply apologize. The sign was hidden by my trolley. I will leave right now" smile

or

p - "Good morning sir. I wish you a very nice day!" smile 
I was familiar with these communicative scripts, having encountered them in other training settings that I documented in my ethnography of Rome's employability programs. I asked Carlo about the relevance of these instructions. Carlo noted that even though these scripts simplify interactions, employers use them to measure workers' performances. This is the type of communication that employers expect workers to produce. Not accommodating this type of language, according to Carlo, signals workers' unwillingness to align themselves with specific professional norms, which then complicates their ability to maintain their job or get stable work contracts. His aim was to empower them, to provide them with what they need to succeed, even if some of the issues he dealt with were ridiculous.

Mira, Maria, and Mais took Carlo's instructions seriously. I observed them while they were reading the interactions and commenting on the scripts. Mira remarked that she would not always be able to smile, especially after a long shift. We exchanged stories of night shifts when after long hours of work people feel unable to talk to anybody anymore. Mais found these scripted interactions comical; she made faces and caricatured the interactional situations. Maria wondered how to react to rude customers or sexual harassment, situations that most of them had experienced in the past. Nevertheless, all of them agreed that following these instructions would be beneficial.

Carlo's coaching did not end with these informal sessions. He would call up the three women to see how they were doing. He also called their employers to see if there were any issues. Gatekeeping, he explained, does not end once an individual he is working with gets a job. His work includes supporting workers in their workplaces and making sure that they keep their jobs.

One day for example, while I was observing one of Carlo's counseling sessions with a woman from Mali, I documented how he intervened for Mira. She had refused to comply with the hotel's dress code. As Carlo explained to me, chambermaids at that hotel were required to wear short, kneelength skirts, and wear their hair down. Mira did not want to show her legs and usually wore a headscarf. The line manager had insisted that workers needed to comply with the hotel's dress code, since it corresponded to the hotel's brand and corporate identity and every worker was an ambassa- 
dor of this brand. Given his good relations with the hotel's manager, Carlo was able to negotiate a compromise. Mira's legs could be covered with black leggings; she would not be allowed to wear a headscarf, but the manager allowed her to wear a hairnet.

Carlo explained that he had intervened similarly on behalf of Maria who, thanks to her previous restaurant work experience, was transferred to the restaurant of the hotel where she worked as a waiter. Maria, Carlo said, was happy about this change since she did not like working as a chambermaid. Afterwards, however, there had been some tensions with one of her shift leaders who was afraid that Maria's ethnicity - she was seen as being of Sinti origin, an ethnic designation that in Italy is usually associated with petty crime and moral corruption-could be negatively perceived by the customers. He therefore suggested sending Maria to the laundry service. Maria resisted this removal and asked to stay in the restaurant. Carlo then intervened with the hotel manager, and they both agreed to send Maria to the restaurant's kitchen, where she was still working with food, but in a less visible position. According to Carlo, this solution was acceptable to Maria, who was happy not to go back to chamber service.

Carlo's interventions allowed the three individuals to be employed beyond the summer season. While their positions had to be renewed every year and their salaries were still at the bottom of what workers in tourism earn, this solution allowed them to have a minimum level of professional stability. Before elaborating on the role that language and communication played in Carlo's attempt to promote these women's access to more stable work situations, I present a second case that helps me complexify our understanding of the communicative strategies mobilized to manage the value of transnational workers' labor power as well as the value of the commodities they produce.

\section{Enterprising workers}

The second case involves the social cooperative Libertà e Giustizia Sociale, which works with ex-prisoners who have difficulties entering the formal job market. I focus on a project that was led by Fiona, one of the cooperatives' social workers, which consisted of 
launching an agricultural business involving ex-prisoners with "a migration background." This purpose of this business was to produce organic vegetables, bread, and biscuits that would be sold at local farmers' markets and in selected shops. Fiona also planned to open a small store, somewhere in an affordable area on the outskirts of Rome.

When I first met Fiona, she explained that this entrepreneurial project involved her collaborating with the ex-prisoners she had selected. Each member involved in the project had been distributed a share of the responsibilities in the project according to their strengths. Fiona recruited Andrey, a Bulgarian man, to supervise the production of vegetables. Andrey had farming experience; he had had his own farm back in Bulgaria. Fiona chose two brothers from Afghanistan to help Andrey with the work in the fields. They had previously worked in Italy's tomato industry and did not need to learn the craft. For the kitchen, where bread and biscuits were produced, Javed was chosen. Javed had his own bakery in Iran before leaving the country. Fiona herself was responsible for writing emails, texts, and reports, negotiating with partners and authorities, as well as editing marketing texts for flyers, packaging, and the website.

I followed the project in summer and autumn 2015 and spent weeks in the fields and in the kitchen, as well as a lot of time in Fiona's car that she used to get to meetings with partners, service providers, and authorities. In those months, Fiona was busy with the opening of the cooperative's shop. The profit made from the sale of their products in organic shops and the farmers' markets was not enough to cover the production costs. Fiona needed to find alternative channels of distribution.

Therefore, she had identified an empty location in one of Rome's suburbs that was cheap enough for the cooperative to rent. Despite the ideal location close to a working-class housing estate, the site was not ready for use and had to be refurbished. A plumber had to reorganize the pipes, the walls had to be repainted, the rooms had to be tiled and insulated, 
and the bathroom and the kitchen needed to be adapted to meet the hygiene standards to which every commercial space must adhere. To raise additional funds for these refurbishments, Fiona also asked for financial support from some local foundations that sponsored social cooperatives. This required the drafting of business plans that would be submitted to the foundations for evaluation and approval.

Fiona had done this type of work before, but still struggled with the technical register and communicative genre that this exercise required. She discussed several drafts with a friend who worked in marketing and who later on in the process also helped with the production of the cooperative's marketing texts. He made her aware of the instructions available on the internet that help future entrepreneurs write successful business plans. On the website of a US consulting firm, a guide suggested six pieces of advice:

1. Clearly state what you're asking for.

2. Explain your business in terms of a problem and solution.

3. Describe your target customer based on personality type, income level, age, gender.

4. Outline the other businesses that exist in your space.

5. Explain what makes you unique and advantageous.

6. Explain exactly how your business works.

(https://fitsmallbusiness.com/business-plan/; accessed on April 4, 2016)

Along with her friend's advice, Fiona used these guides to turn her text into a successful business plan. Sometimes these instructions provided her with templates allowing her to structure her ideas and communicate them convincingly. In other cases, these instructions represented a pool of technical concepts that she could refer to in order to enrich her text and sound professional. Despite the challenges encountered in the writing process, she eventually convinced the sponsors of the potential of her project and raised the funds necessary for the refurbishments. 
In addition to her ability to deal with stakeholders and to draft technical texts, what Fiona was also bringing to the project were her own social relations, which she utilized to benefit the cooperative, in compensation for the lack of financial resources available. The kitchen, for example, was shared with a partner organization with which Fiona had collaborated in the past. The recipes for the bread and biscuits were provided by Fiona's mother. Fiona's brother, who had contacts with farmers in southern Italy, was able to provide the cooperative with the necessary tools to work in the fields, including a small tractor. All of this was in addition to the above-mentioned friend who agreed to produce the promotional material for free.

Fiona's network was particularly powerful when it came to the commercialization of the products. During my documentation of the cooperative's stand at a farmers' marketwhich was organized in one of Rome's old market halls every Sunday, where the local municipality had granted the cooperative a place that was reserved for organizations doing public interest work-I observed that none of the individuals who were involved in the project were ever present. Fiona explained to me that after the first couple of Sundays, she had decided to use volunteers for the work on the stand, especially members of her family. Initially Andrey or Javed had been at the stand and sold the products to customers, but some customers, she said, had reacted negatively to their presence. Some had made comments about Javed and mentioned that they did not want to buy food from a non-local producerJaved's communicative behavior and the color of his skin being understood by customers as a sign of "foreignness." For Fiona, sending one of her family members to sell products at the farmers' market was a means of creating a climate of acceptance for transnational workers' presence and for the products they sold, i.e. to navigate the colonial ideologies that structure the ways transnational workers are perceived in Italy (mainly as unskilled, lazy workers, and sometimes as criminals or as morally corrupt individuals) and that in times of so-called 
"economic crises" and high rates of unemployment contribute to an ulterior worsening of transnational workers' status in public discourse.

While documenting the interactions at the stand, I noted that this removal of the racialized workers' bodies from the spaces where products were sold coexisted with a communicative regulation of how products were promoted to customers. During the Sundays that I spent at the farmers' market, Fiona's father, Massimo, agreed to help out on the stand. Massimo has a background in journalism; he is retired now, but used to write for a leftist national newspaper. Currently, however, Massimo writes for various political blogs and at weekends volunteers at his daughter's cooperative. While observing Massimo selling the biscuits, salads, and tomatoes, I noted that he kept changing the ways he presented the products. Initially, I did not understand this communicative variability. In the case of an elderly woman, who was interested in the honey biscuits, he explained that this cooperative was led by migrants and that the stand was part of a socioeconomic integration project. He mentioned Javed, the baker. He explained how Javed had exchanged recipes with Fiona's mother, his wife, and how they used to bake these products together. In another case, two young women inquired about the origins of the zucchini flowers to which Massimo credited Fiona's collaborator, Andrey, as having cultivated in the small greenhouse that Andrey had built. In another case, however, after being asked by a young man about the bread, he omitted the fact that these products were produced by Andrey and his team and explained that the producers were all ex-prisoners and that this organic farming was part of a social integration project. In other cases, he completely avoided mentioning that all this was a social project and just pointed out the quality of the products.

I asked about the logics regulating this variability. Massimo explained that depending on the clients, he mobilized a different strategy. From the individuals' appearance, he could anticipate how they would react to the fact that the cooperative was led by a group of ex- 
prisoners with a transnational background, that this project was meant to support the professional integration of these individuals, and that the products themselves were also produced by these same people. Massimo added that in one of the five entrances of the market hall a young peddler from Senegal, called Moussa, was selling handkerchiefs. In exchange for ten euros, Massimo explained, every Sunday morning, Moussa helped him unload the merchandise from his truck and arrange it on the stand. One way of finding out customers' attitude toward their products, Massimo noted, was to observe them interacting with Moussa: Were they talking to him? Were they buying his products? Ignoring him? Insulting him? Depending on their reactions to Moussa, he would then adapt his story. Often, he was not able to identify these peoples' attitudes, he explained, but often just paying attention to how they spoke, their clothes, and the way they moved around was indicative of their ideological positioning.

In the weeks after I had met Massimo, rumors about the cooperative started to circulate among the customers. Some of them approached Massimo asking about the products: who produces these vegetables? Do the workers have a work permit? Is the food produced in Italy? Is it really organic? Do you have the necessary certificates? In one of the many conversations I had with Fiona about the challenges posed by such an entrepreneurial project, Fiona explained that she had heard from one of her customers that some other farmers who were selling their products at that market had told her not to buy Massimo's products since they were of dubious origin. Similar rumors had also circulated from customer to customer after having received contradictory information about the products they had bought. In other words, Massimo's tactic had both advantages and drawbacks. While adapting his promotional strategy to what he thought were the values and positioning of his customers, the variability of his communicative practice created confusion and suspicion. 
These challenges that emerged during the selling of the products and that continued to manifest themselves in other activities carried out by Fiona and the other members of the cooperative were emblematic of larger issues mobilized by this tactic. The entrepreneurial project was only working, this is how Fiona made sense of it, with the support of the resources that Fiona could bring to the project. According to Fiona, existing on the "free market" necessitates the involvement of a whole raft of other gatekeepers and helpers who are volunteers and are therefore unpaid. This strategy was not only meant to compensate for the lack of financial and human resources. It also allowed the cooperative to cope with the increasing stigmatization of the transnational workforce in Italy (accusing them of stealing Italians' jobs) as well as with the racializing discourses that associate commodities produced by transnational workers with ideas of bad quality, informality, and a lack of hygiene. However, this business model came with issues involving not only ambiguity in terms of what this entrepreneurial project is and does, but also in terms of (in)visibility, as well as (de)valuation of those individuals producing the commodities.

In the next section, I take the two former cases as a starting point to theoretically address these tensions and challenges and to discuss the multiple ways talk is involved in these processes. I will focus on the ways talk is strategized to promote change and at the same time on the costs that this strategizing involves for transnational workers.

\section{Strategizing around language and communication}

How does language contribute to the everyday "doing" of the forms of solidarity promoted by these social cooperatives? What are the theoretical implications of these two cases for how we need to understand the role of speaking for the production of change? While Donne e Lavoro and Libertà e Giustizia Sociale invest in different types of projects, we can identify strategies that cut across all projects and activities. 
First, language is used by Carlo and Fiona, as well as by Massimo, as a powerful communicative resource to imbue commodities with qualities that point to specific regimes of value and knowledge that then shape, or are shaped by, the desires of consumers (Gal 2017; Heller 2010). Indeed, language, as a communicative resource that mediates specific values and forms of affect, allows for the packaging of the commercialized commodity and the raising of its value on specific markets (Lorente 2017). In the case of Libertà e Giustizia Sociale, strategic ways of narrating the origins and history of production of the products commercialized at the farmers' market allow Massimo not only to flexibly adapt the social meaning of his product to the imagined morally and culturally marked tastes of the customers he encounters on this stand (Cavanaugh 2016), but Massimo's ability to speak persuasively about his products, also enables him to highlight or invisibilize those aspects of his commodities and their history of production that might be seen as disturbing (Duchêne and Del Percio 2014). Interestingly, along with Massimo and Fiona, Carlo is also aware of this role of talk for the marketization of products and services. While in the case of the agricultural project, the objects of communicative manipulation are vegetables, bread, and biscuits, in Carlo's case the marketized commodities are human beings. The scripts that Mira, Maria, and Mais are asked to engage with allow them to adapt their own personae to the imagined expectations of customers, line managers, and employers (Allan, 2013; Duchêne 2009). More particularly, the interactions presented by the textbook are a means of helping the three workers align themselves with ways of behaving toward and relating to interlocutors that are said to be linked to types of personae that are imagined as being perceived as particularly desirable (Boutet 2001a). Since, semiotically speaking, behaving and being become the same thing (Irvine and Gal 2000), being able to embody this commodity register (Agha 2011) allows workers to raise the value of their own labor power and challenge regimes of 
precarization that affect, not only, but particularly, transnational workers in Italy (Del Percio, 2017).

Second, in addition to their capacity to imbue commodities with social values, communicative practices also allow social workers to do work (such as engaging with stakeholders, coordinating work activities, marketing products, advising workers, and so on) (Boutet 2001b) and to manage valuable social relations and networks of reciprocity and obligation (Vigouroux 2013). Carlo and Fiona's ability to communicate and engage with a network of interlocutors who are able to distribute and give access to valued social resources is due, among other things, to their capacity to enact forms of communicative expertise that point to relations of sharedness, reciprocity, and loyalty (Narotzky and Besnier 2014). These relations exist within complex cosmologies of credit (Chu 2010) that allow gatekeepers to capitalize on their own social networks. These social relations are then turned into other resources that are put at the service of individuals such as Mira, Maria, and Mais as well as Javed and Andrey. From this point of view, talk is enmeshed with an economy of affect (McElhinny 2010) and becomes itself a resource that can be directly exchanged with other resources (Bourdieu 1977).

It is important to note that both Fiona's and Carlo's strategizing and speculating around talk (Duchêne and Daveluy 2015) is not the product of their rational intentions, nor is it an expression of their free will. Social workers' strategizing is, rather, indicative of larger discourses about language, social work, transnational workers, unemployment, socioeconomic independence, and social equality that frame their professional practices and define the limits of possibility of the forms of change that social cooperatives can produce.

First of all, their professional practices are informed by ideologies of difference. These conflate language and membership and legitimize social inequality on the basis of individuals' capacity to master what in a specific space, at a given moment in time, is considered to be the 
legitimate language (Gal 1989). Accordingly, for social cooperatives committed to solidarity and change, transnational workers' presumed inability to produce legitimate speech makes them vulnerable and therefore in need of help. Social workers tend to compensate for workers' presumed communicative deficit either by equipping these individuals with what is considered to be adequate communicative behavior or, as in the case of Fiona and Carlo, by literally putting themselves at the disposal of projects promoting change and solidarity.

Second, Fiona and Carlo's activities to encourage transnational workers' professional integration are linked to wider assumptions about the social value of work. In many Western societies, including Italy, becoming a citizen is conflated with becoming a worker, i.e. doing productive labor that contributes to the prosperity of the individual and to society at large (Mezzadra and Neilson 2013). Being a worker not only allows you to be seen as a morally integral persona, but it also allows you to pay taxes, and therefore to be entitled to welfare and to participate (with more or less right) in the imagined community that we have learned to call a nation. For social cooperatives, helping displaced individuals to challenge positions of social and economic marginality always involves facilitating their access to formal work, informal work needing to be avoided since it is generally associated with forms of disorder, petty criminality, and moral corruption.

Third, social workers' modes of reasoning around specific modes of communicating is linked to widely shared theories of human capital (Becker 1993) that assume that the individuals' value on the job market depends on the set of investments that individuals are ready to make in themselves, i.e. in their willingness to acquire a whole set of capacities and forms of knowledge that will allow them to be more desirable socially and professionally (Urciuoli 2008; Vigouroux 2017). This theory then, is intrinsically linked to another discourse that frames the work of cooperatives, namely one that shifts the burden for socioeconomic integration to individuals (those considered to be in need) and that makes them responsible for 
their own professional success or exclusion (Flubacher, Duchêne, and Coray 2018). Indeed, especially in Carlo's case, the understanding of language as a condition for the performance of professionalism and the stabilization of an individual's professional situation means that transnational workers' ability to be successful is framed as a personal choice, i.e. is made dependent on their willingness and capacity to acquire the professional registers considered to be desirable on the job market. This connection between the willingness to acquire specific professional registers and access to labor that underpins the work of many social cooperatives also contributes to the naturalization of the structural constraints and ideological impediments that regulate individuals' access to resources such as labor.

Fourth, social workers' operations on the ground are framed by larger discourses of value that link the quality of commodities (both things and workers) to a larger moral order and hierarchize these commodities according to their ability to point to, or stand for, this order. What counts as good quality is not dependent on whether or not a given commodity fulfils its imagined use-value, but rather whether it bears the traces of values that matter to people. Under current conditions of capitalist expansion, quality seems to be linked to two seemingly contradictory notions: anonymity, which means the capacity of a commodity to erase its own history of production (e.g. a commodity's connection with dirt, mass production and seriality, work exploitation, and suffering) and at the same time authenticity, which means its anchoring within a whole set of culturally marked experiences that are linked to histories and places perceived as particularly desirable (see Woolard 2016 for an elaboration of this distinction). Fiona, Carlo, and Massimo are aware of these dynamics, since in their work in helping transnational workers they keep addressing different regimes of value in order to maximize the outcomes of their activities. Massimo's variable marketization of the products sold at the farmers' market needs to be seen as a response to current desires for local and authentic food, arguing that good and healthy food is food produced at a specific place, by 
people that we know and according to production techniques that resemble those of our ancestors (see Cavanaugh 2016 for a similar line of argument). Interestingly, in a society that makes charity a moral imperative, this equation linking good food to local food, is not (or not always) in contradiction with the equation between linking good food with food produced for a good cause, which makes food produced by specific types of transnational workers particularly valuable. Similarly, Carlo tries to direct the conduct of workers toward a mode of being that he imagines to be highly valued in spaces where workers are meant to serve customers and that asks workers to embody forms of communicative behavior that are usually associated with how women are imagined (and often required) to behave, i.e., to be submissive, caring, reassuring, smiling, and indulgent (Cameron 2000).

Finally, the practices documented are framed by Italy's history of colonialism that continues to affect how individuals in Italy relate to what they consider to be the "other," i.e. "foreigners," especially people seen as belonging to different racial or ethnic backgrounds. Indeed, in spite of Italy having ceased to be a colonial power, transnational workers continue to be seen by employers, co-workers, and customers as culturally and intellectually inferior beings and therefore as less able professionals (De Donno and Srivastava 2006). This involves a devaluation of their work power as well as a devaluation of the products and services they produce. For social workers in cooperatives then, promoting transnational workers' professional integration means supporting them in their struggle to cope with the colonial stigma with which many of them are confronted on a daily basis.

\section{Conclusion : Language and its costs}

It is difficult to assess the extent to which social workers' investment in talk was effectively a trigger of change for transnational workers. We cannot say with certainty that the fact that Mira, Maria, and Mais were able to keep their jobs was due to the communicative scripts discussed with Carlo, nor can we make any conclusions about the impact of Fiona's 
and Massimo's communicative capacity on the success of the agricultural project, even if their involvement in the project has contributed significantly to the fact that two years after my fieldwork, this business continues to exist. However, what can be said is that their activities and modes of reasoning come at a cost, especially for the transnational workers.

What became clear was that in both presented cases, this construction of language and communication as key resources for economic success led to a division of work between social workers and transnational individuals that reproduced hierarchies that are emblematic of the way society is structured and stratified in Rome. In the case of the counseling session, the identification of scripted communicative behavior as a resource that allows individuals to be seen as professional by those who control access to employment opportunities, placed Carlo in a position of superiority in relation to the three women, as the one holding and owning the legitimate knowledge about how to behave appropriately in a professional context versus the ones who need to learn what it means to be professional. In the case of the agricultural project, strategizing around talk involved a hierarchization between Fiona and Massimo who did the valued, visible, and intellectual jobs, versus the work of Javed and Andrey who were forced to do the less valued and less prestigious manual jobs involving the production of bread and biscuits as well as the work in the fields.

The speculation around language also affected the ways transnational workers understood themselves and were perceived by others. While Carlo's training instructions allowed individuals to socialize themselves (in a Durkheimian sense) in a register that is seen as particularly desirable, this script also required the three women to adopt a specific posture that forces them to discipline their own bodies and communicative practices and that positions them as subordinated subjects both toward their employers and their customers (Martin Rojo 2018). This then contributes to a reproduction of historically naturalized, asymmetrical relations between what in the colonial era used to be the master and the servant (Lorente 
2017). Similarly, Massimo's communicative variability allows him to navigate the forms of affect that structure the encounters of consumers with the transnational "other," but at the same time contributes, in certain cases, to the promotional exploitation of transnational workers' stories and selves, and in other cases to the invisibilization and erasure of the workers' bodies and of their work power.

In other words, this article has shown that social cooperatives' investment in the management of labor inequality for transnational workers is not that dissimilar from how nation-states govern labor and the transnational circulation of workers (Allan and McElhinny 2017; Duchêne, Moyer, and Roberts 2013). Like the state, social cooperatives mystify language as a condition of access and tend to forget, or to omit the fact that, in spite of its capacity to open doors, language is intrinsically entrenched with histories of exclusion, stratification, exploitation, domination, and subordination (Heller and McElhinny 2017). I have also demonstrated that the forms of resistance expressed by social workers, while well intentioned, are saturated by racializing and gendered ideologies of language, work, and the self that complicate social cooperatives' capacity to think and act out of modes of reasoning, intervention, and transformation that are predefined by histories of modernity that continue to exert control over how resources are distributed and inequality is produced.

\section{Reference list}

Agha, Aasif. 2011. “Commodity Registers.” Journal of Linguistic Anthropology 21, no. 1: $22-53$.

Allan, Kori. 2013. "Skilling the Self.” In Language, Migration and Social Inequalities, edited by Alexandre Duchêne, Melissa Moyer, and Celia Roberts, 56-80. New York: Multilingual Matters. 
Allan, Kori, and Bonnie McElhinny. 2017. "Neoliberalism, Language, and Migration.” In The Routledge Handbook of Migration and Language, edited by Susan Canagarajah, 79101. New York: Routledge.

Becker, Gary. 1993. Human Capital. Chicago: The University of Chicago Press.

Bourdieu, Pierre. 1977. "The Economics of Linguistic Exchange.” Social Science Information 16: $645-668$

Boutet, Josiane. 2001a. "La part langagière du travail: Bilan et évolution." Langage et société 98, no. 4: $17-42$.

Boutet, Josiane. 2001b. “Le travail devient-il intellectuel?” Travailler 6, no. 2: 55-70.

Cameron, Deborah. 2000. "Styling the Worker: Gender and the Commodification of Language in the Globalized Service Economy." Journal of Sociolinguistics 4, no. 3: $323-347$.

Cannavò, Salvatore. 2018. Mutualismo. Ritorno al futuro per la sinistra. Rome: Edizioni Alegre.

Cavanaugh, Jillian. 2016. "Talk as Work: Economic Sociability in Northern Italian Food Heritage Production." Language and Communication 48: 41-52.

De Donno, Fabrizio, and Neelam Srivastava. 2006. "Colonial and Postcolonial Italy." Interventions 8, no. 3: 371-379.

Del Percio, Alfonso. 2016. "The Governmentality of Migration: Intercultural Communication and the Politics of (Dis)placement in Southern Europe." Language and Communication 51: 87-98.

Del Percio, Alfonso. 2017. “Engineering Commodifiable Workers: Language, Migration and the Governmentality of the Self." Language Policy 172: 239-259. 
Del Percio, Alfonso, and Sarah Van Hoof. 2017. "Enterprising Migrants: Language and the Shifting Politics of Activation.” In Language, Education and Neoliberalism, edited by Mi-Cha Flubacher and Alfonso Del Percio, 140-162. Bristol: Multilingual Matters.

Duchêne, Alexandre. 2009. "Marketing, Management and Performance: Multilingualism as Commodity in a Tourism Call Centre.” Language Policy 8, no. 1: 27-50.

Duchêne, Alexandre, Melissa Moyer, and Celia Roberts, eds. 2013. Language, Migration and Social Inequalities. New York: Multilingual Matters.

Duchêne, Alexandre, and Alfonso Del Percio. 2014. "Economic Capitalization on Linguistic Diversity: Swiss Multilingualism as a National Profit?” In Multilingual Encounters in Europe's Institutional Spaces, edited by Johann W. Unger, Michal Krzyzanowski, and Ruth Wodak, 77-104. New York: Bloomsbury.

Duchêne, Alexandre, and Michelle Daveluy. 2015. "Spéculations langagières: Négocier des ressources aux valeurs fluctuantes.” Anthropologie et Sociétés 39, no. 3: 9-28.

Federalberghi. 2009. La pulizia professionale delle camere d'albergo. Roma: Istituto Internazionale di Studi e Documentazione Turistico Alberghiera "Giovanni Colombo".

Flubacher, Mi-Cha, Alexandre Duchêne, and Renata Coray. 2018. Language Investment and Employability. Basingstoke: Palgrave Macmillan.

Gal, Susan. 1989. "Language and Political Economy.” Annual Review of Anthropology 18: $345-367$.

Gal, Susan. 2017. “Qualia as Value and Knowledge.” Signs and Society 5, no. 1: 128-153.

Heller, Monica. 2010. "The Commodification of Language.” Annual Review of Anthropology 39: $101-114$.

Heller, Monica, and Bonnie McElhinny. 2017. Language, Capitalism, Colonialism: Toward a Critical History. Toronto: University of Toronto Press. 
Irvine, Judith, and Susan Gal. 2000. "Language ideology and linguistic differentiation." In Regimes of language: Ideologies, polities, and identities, edited by Paul V. Kroskrity, 35-84. Santa Fe: School of American Research Press.

Lorente, Beatriz P. 2017. Scripts of Servitude: Language, Labor Migration and Transnational Domestic Work. Bristol: Multilingual Matters.

Martin Rojo, Luisa. 2018. "Neoliberalism and Linguistic Governmentality." In The Oxford Handbook of Language Policy and Planning, edited by James W. Tollefson and Miguel Pérez-Milans, 544-567. Oxford: Oxford University Press.

McElhinny, Bonnie. 2010. "The Audacity of Affect: Gender, Race, and History in Linguistic Accounts of Legitimacy and Belonging." Annual Review of Anthropology 39: 309328.

Mezzadra, Sandro, and Brett Neilson. 2013. Border as Method, or the Multiplication of Labor. Durham: Duke University Press.

Narotzky, Susana, and Niko Besnier. 2014. "Crisis, Value, and Hope: Rethinking the Economy." Current Anthropology 55, no. 9: 4-16.

Neri Serneri, Simone, ed. 2012. Verso la lotta armata: La politica della violenza nella sinistra radicale degli anni Settanta. Bologna: Il Mulino.

Thomas, Antonio. 2004. “The Rise of Social Cooperatives in Italy.” Voluntas 15, no. 3: 243263.

Satgar, Vishwas. 2007. “Cooperative Development and Labour Solidarity: A Neo-Gramscian Perspective on the Global Struggle Against Neoliberalization." Labor, Capital and Society 40, no.1-2: 56-79.

Urciuoli, Bonnie. 2008. "Skills and Selves in the New Workplace." American Ethnologist 35, no. 2: 211-228. 
Vigouroux, Cécile. 2013. "Informal Economy and Language Practices in the Context of Migrations" In Language, Migration and Social Inequalities, edited by Alexandre Duchêne, Melissa Moyer, and Celia Roberts, 225-247. New York: Multilingual Matters.

Vigouroux, Cécile. 2017. "Rethinking (Un)skilled Migrants: Whose Skills, What Skills, For What, and For Whom?" In The Routledge Handbook of Migration and Language, edited by Susan Canagarajah, 312-329. New York: Routledge.

Woolard, Kathryn. 2016. Singular and Plural, Oxford: Oxford University Press.

Xiang, Biao, and Johan Lindquist. 2014. "Migration Infrastructure." International Migration Review 48: 122-148. 